\title{
PENGEMBANGAN MOBILE LEARNING BERBASIS ANDROID PADA MATA PELAJARAN REKAYASA PERANGKAT LUNAK DI SMK SULTAN TRENGGONO KOTA SEMARANG
}

\author{
Dania Ayu Wulandari', Agus Murnomo², Hari Wibawanto ${ }^{3}$, Agus Suryanto ${ }^{4}$ \\ 1,2,3,4 Teknik Elektro, Universitas Negeri Semarang \\ Email: 1daniaayuwulandari@students.unnes.ac.id, ${ }^{2}$ amurnomo@yahoo.com, ${ }^{3}$ hariwibawanto@mail.unnes.ac.id, \\ 4i agusku2@mail.unnes.ac.id
}

(Naskah masuk: 11 Agustus 2018, diterima untuk diterbitkan: 02 Oktober 2019)

\begin{abstract}
Abstrak
Perkembangan jumlah pengguna smartphone sudah merambah di kalangan siswa. Hal ini dapat dimanfaatkan sebagai media pendukung proses pembelajaran. Penggunaan media merupakan salah satu komponen metode untuk mencapai tujuan pembelajaran. Berdasarkan observasi di SMK Sultan Trenggono Kota Semarang, media pembelajaran masih terbatas pada slide show power point yang monoton, e-book, dan LKS (Lembar Kerja Siswa) atau buku-buku teks lainnya yang dinilai kurang memenuhi kelayakan. Penelitian ini bertujuan untuk mengetahui: (1) pengembangan media, (2) kelayakan media dan; (3) penilaian kemudahan dan kemanfaatan penggunaan media oleh siswa dan guru. Mobile learning didefinisikan sebagai model pembelajaran menggunakan perangkat IT (information technology) genggam dan bergerak. Model pengembangan yang digunakan adalah 4-D (Four D Models), yaitu: define (pendefinisian), design (perancangan), develop (pengembangan), dan disseminate (penyebaran). Berdasarkan penilaian kelayakan oleh validator media menunjukkan bahwa: aplikasi mendapat penilaian sebesar 86,93\% dari ahli media dan 87\% dari ahli materi. Sedangkan hasil uji coba menunjukkan nilai kemudahan dan kemanfaatan penggunaan aplikasi sebesar $87,5 \%$ oleh guru dan $82,27 \%$ oleh siswa. Hal ini menunjukkan bahwa media sangat layak untuk digunakan, mudah, dan bermanfaat dalam proses pembelajaran.
\end{abstract}

Kata kunci: media, mobile learning, smartphone

\section{MOBILE LEARNING BASED ON ANDROID DEVELOPMENT ON SUBJECTS OF SOFTWARE ENGINEERING AT SMK SULTAN TRENGGONO KOTA SEMARANG}

\begin{abstract}
The growth number of smartphone users has penetrated among the students. This can be used as a supporting media of the learning process. The use of media is one component method to achieve learning objectives. Based on the observations at SMK Sultan Trenggono Kota Semarang, the learning media is still limited to the monotonous power point slide show, e-book, and LKS (student worksheet) or other textbooks that are considered less feasibile. This study aims to determine: (1) media development, (2) media feasibility, and (3) assessment of ease and usefulness of media usage by students and teachers. Mobile learning is defined as a learning model using IT (information technology) handheld and mobile devices. The development model used is 4-D (Four D Models), which are: define, design, develop, and disseminate. Based on the feasibility assessment by the media validator shows that: the application received an assessment is $86.93 \%$ of media experts and $87 \%$ of material experts. While the test results show the value of ease and usefulness of application usage is $87.5 \%$ by teachers and $82.27 \%$ by students. This shows that the media is very feasible to use, easy, and useful in the learning process.
\end{abstract}

Keywords: media, mobile learning, smartphone

\section{PENDAHULUAN}

Saat ini perangkat mobile khususnya smartphone sudah merambah di berbagai kalangan masyarakat, mulai dari anak-anak, remaja, hingga dewasa. Alasannya, karena perangkat mobile dapat membantu mengerjakan beberapa pekerjaan penting atau kebutuhan mereka (Muharum, dkk, 2017:48). Munculnya smartphone telah banyak mengubah cara dalam mengakses informasi yaitu dapat memberikan kemudahan dan kecepatan akses informasi dan komunikasi (Rotondi, Stanca, dan Tomasuolo, 2017:17). Akan tetapi, penggunaan smartphone mayoritas dimanfaatkan untuk akses sosial media sehingga menyebabkan sedikitnya penggunaan dalam bidang pendidikan (Muyaroah dan Fajartia, 2017:80). Hal ini didukung Setiawan, Astuti, dan Khairina (2014:24) yang menyebutkan bahwa sistem operasi Android merupakan sistem operasi mobile 
(smartphone) yang paling banyak digunakan dan diminati pengguna untuk berkomunikasi maupun mencari suatu informasi.

Berdasarkan kuesioner yang dibagikan kepada siswa SMK Sultan Trenggono kelas X RPL sebanyak 15 siswa, 13 memiliki smartphone berbasis android atau sekitar $87 \%$ dari jumlah siswa. Kebanyakan mereka sudah menggunakan smartphone selama 2-5 tahun. Rata - rata siswa menghabiskan waktu 9,5 jam perharinya dalam menggunakan smartphone, mulai dari digunakan untuk browsing, chatting, game, dan sosial media. Hal ini menjadi potensi untuk mengoptimalkan pemanfaatan smartphone sebagai media pembelajaran didukung dengan 93,3\% siswa setuju jika pembelajaran diadakan menggunakan perangkat mobile untuk membantu dalam penguasaan materi.

Penggunaan media merupakan salah satu komponen metode untuk mencapai tujuan pembelajaran. Media merupakan alat yang berfungsi untuk menyampaikan pesan dari pengirim pesan kepada penerima pesan (Falahudin, 2014:108). Berdasarkan observasi di SMK Sultan Trenggono Kota Semarang, media pembelajaran yang digunakan masih terbatas pada slide show power point yang monoton, e-book, dan LKS atau buku-buku teks lainnya yang dinilai kurang memenuhi kelayakan. Perlu adanya pengembangan model pembelajaran dengan media yang menarik untuk mengatasi kebosanan dan kesulitan siswa dan media yang dikembangkan harus memenuhi syarat kelayakan, yaitu isi, kebahasaan, sajian dan kegrafikan (Depdiknas, 2008:28).

Hidayat dan Herlambang (2014:2) menjelaskan model pembelajaran dengan didominasi aktivitas bertatap muka dan kurangnya implementasi teknologi memiliki beberapa kekurangan, diantaranya: sumber belajar yang terbatas, proses pembelajaran monoton dan kurang menyenangkan, serta pengumpulan tugas yang kurang tertib. Saat ini, perkembangan teknologi informasi mampu mengolah, mengemas dan menampilkan informasi baik secara audio, visual, dan audio visual bahkan multimedia sehingga menjadi alternatif pemecahan masalah pendidikan sebagai salah satu bentuk model pembelajaran berbasis teknologi (Darmawan, 2016:1). Hal ini didukung oleh Taufiq, Amalia, dan Parmin (2017:1473) yang menyatakan bahwa perkembangan teknologi multimedia menjanjikan potensi besar dalam hal cara belajar, memperoleh dan mengatur suatu informasi. Kemudian menurut Suyanto dalam Syafrizal, Ernawati dan Dwiandiyanta (2015:9) menjelaskan bahwa penggunaan media yang terdiri dari beberapa komponen, diantaranya: teks, gambar, suara, video, dan animasi menimbulkan seseorang dapat menangkap $50 \%$ dari apa yang dilihat dan $80 \%$ dari apa yang dilihat, didengar dan berinteraksi sehingga media interaktif dapat meningkatkan efektifitas penyerapan materi. Penyampaian konsep materi dengan melibatkan siswa secara langsung akan lebih baik dibandingkan dengan siswa hanya mendengarkan dan mengamati secara pasif. Hal ini memiliki peran untuk menimbulkan perhatian, mudah mengingat, mempersamakan pengalaman dan persepsi yang sama (Wibawanto, 2017:5).

Mobile learning merupakan salah satu variasi pembelajaran dengan memanfaatkan IT (information technology) genggam dan bergerak untuk belajar atau mengakses materi pelajaran kapanpun dan dimanapun (Ariputri dan Supraptono, 2014:39). Hal ini adalah satu bentuk pemanfaatan menggunakan teknologi multimedia yang bersifat interaktif yang membantu kecepatan pemahaman siswa terhadap materi pelajaran (Kawuryan, 2014:60). Model pembelajaran mobile learning dapat memusatkan perhatian pada siswa (student centered learning) dengan cara guru sebagai fasilitator dan menyediakan media pembelajaran sehingga dapat menyajikan konten pembelajaran dalam bentuk teks, video, animasi dan multimedia. Hal ini dijelaskan oleh Hapsari, Wibawanto, dan Sudana (2017:30).

Adanya konsep mobile learning, pembelajaran tidak akan dibatasi oleh ruang dan waktu karena fleksibilitas dan portabilitas perangkat yang digunakan sehingga siswa lebih antusias dan memiliki kesempatan belajar dengan ruang pembelajaran yang baru, mudah, bermanfaat, dan menyenangkan. Mobile learning berbasis Android ini dapat dijadikan alat belajar yang berisi materi pembelajaran, seperti: rangkuman materi, soal, animasi, video dan fitur lain yang lebih menarik. Aplikasi media pembelajaran menggunakan smartphone berbasis Android terbukti layak, praktis, dan efisien untuk digunakan dalam pembelajaran (Lu'mu, 2017:6584).

Menurut Hafis dan Supianto (2018), dalam penelitiannya menjelaskan bahwa pembelajaran berbasis aplikasi adalah salah satu metode endless run yang efektif dalam membantu menguraikan ide belajar materi ikatan kimia menggunakan pendekatan mobile game dengan data yang dikumpulkan dari pemain untuk tujuan pembelajaran dan analisis untuk mengatasi kesulitan dan minat siswa. Selain itu, analisis fungsional rancangan game dapat dinyatakan untuk memperkuat ide keabsahan penggunaan perangkat berupa mobile device yang fleksibel dalam pembelajaran berbasis game application.

Hal ini juga dijelaskan oleh Gufron Amirullah dan Restu Hardinata (2017) dalam penelitiannya bahwa produk pengembangan berupa media pembelajaran yang dapat diakses melalui smartphone dapat menarik minat siswa dengan muatan aplikasi yang lengkap dan tampilan menarik maka menjadi inovasi baru yang dapat dimanfaatkan untuk digunakan untuk proses pembelajaran.

Mobile learning yang sudah diterapkan di SMK Sultan Trenggono adalah penggunaan Edmodo. Edmodo merupakan salah satu aplikasi internet berupa social network/ jaringan sosial berbasis 
lingkungan sekolah untuk pembelajaran yang dapat digunakan untuk guru dan siswa dalam mengorganisasikan aktivitas pembelajaran baik berupa penyajian materi, pemberian tugas, dan evaluasi (Putranti, 2013:141). Namun Edmodo yang digunakan masih terbatas untuk kegiatan try out atau persiapan ujian sehingga belum dioptimalkan penggunaannya dalam proses pembelajaran. Berdasarkan uraian tersebut, tujuan dari penelitian ini adalah menghasilkan media mobile learning yang layak, mudah, dan bermanfaat bagi siswa dan guru di SMK Sultan Trenggono Kota Semarang dalam proses pembelajaran.

\section{METODE PENELITIAN}

Penelitian ini akan mengembangkan mobile learning menggunakan media berupa aplikasi android pada mata pelajaran Rekayasa Perangkat Lunak. Penelitian ini menggunakan metode penelitian dan pengembangan atau Research and Development (R\&D). Dijelaskan oleh Sugiyono (2015:297), "metode penelitian dan pengembangan merupakan metode penelitian yang digunakan untuk menghasilkan produk tertentu dan menguji keefektifan produk tersebut". Model pengembangan yang digunakan adalah 4-D (Four D Models), yaitu: define (pendefinisian), design (perancangan), develop (pengembangan), dan disseminate (penyebaran).

Pada tahap define (pendefinisian) yang dilakukan adalah (1) analisis ujung depan, yaitu penentuan masalah dasar yang dialami siswa dalam proses pembelajaran, (2) analisis siswa, yaitu mengetahui karakteristik siswa dan kesulitan yang dialami, (3) analisis tugas, yaitu mengidentifikasi tugas utama yang dilakukan siswa disesuaikan dengan kompetensi inti (KI) dan kompetensi dasar (KD) berdasarkan kurikulum dengan kompetensi keahlian Rekayasa Perangkat Lunak, (4) analisis konsep, yaitu menentukan materi yang akan disampaikan melalui media, dan (5) analisis tujuan pembelajaran, yaitu merumuskan indikator tujuan pembelajaran yang akan dicapai.

Pada tahap design (perancangan) yang dilakukan adalah (1) penyusunan tes acuan, yaitu: menyusun alat untuk mengukur pemahaman siswa terhadap materi, (2) pemilihan media, yaitu: menentukan media yang tepat dan relevan untuk siswa yang ditujukan agar penggunaan media tepat untuk pembelajaran, (3) pemilihan format, yaitu: memilih format media yang terdiri dari: format media, RPP (Rencana Perangkat Pembelajaran), sumber belajar, dan rancangan tampilan, (4) desain awal, yaitu: melakukan perancangan awal yang menjadi pegangan dalam proses pengembangan, meliputi: flowchart, alur navigasi, dan pembuatan storyboard. Flowchart merupakan penggambaran program secara menyeluruh berkaitan dengan urutan proses didalamnya sehingga alur program dari mulai sampai akhir dapat tergambarkan secara jelas (Darmawan, 2017:7). Alur navigasi merupakan rancangan struktur atau alur dari suatu program yang menggambarkan konstruksi antar bagian (Chandra, 2016:9). Sedangkan storyboard merupakan narasi dan visual yang menggambarkan urutan komponen dalam media (Azizah, Butar, dan Wahyuni, 2018:9). Berikut ini alur navigasi produk dan flowchart media.

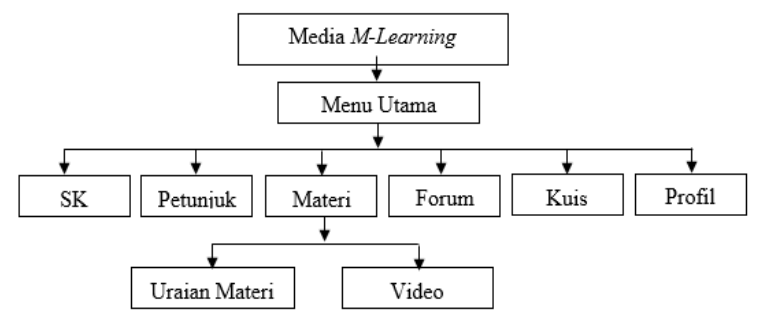

Gambar 1. Alur navigasi aplikasi

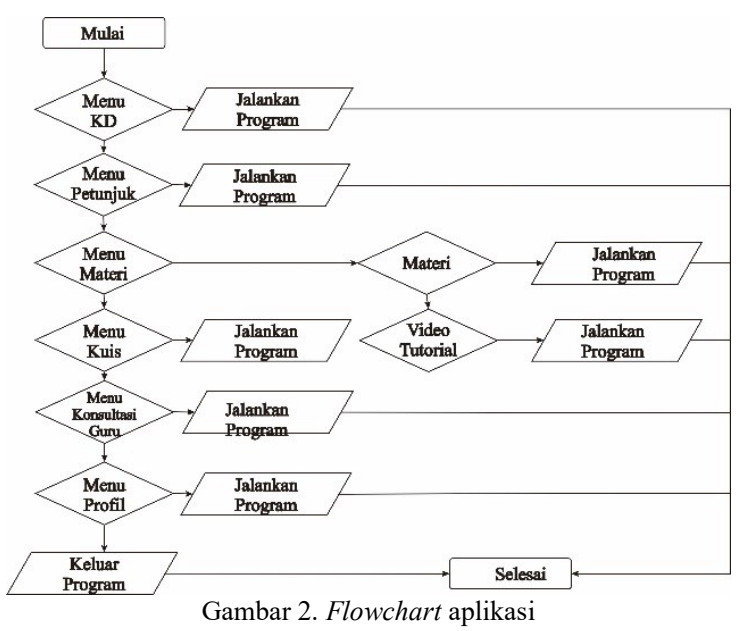

Pada tahap develop (pengembangan) yang dilakukan adalah: (1) mempersiapkan kebutuhan perangkat keras dan perangkat lunak, yaitu:

1) Perangkat Lunak

a. MIT App Inventor 2.0

b. Corel Draw X5

c. Adobe Premiere Pro CS6

2) Perangkat Keras

a. PC/ laptop dengan spesifikasi:

- minimal RAM $4096 \mathrm{Mb}$

- Prosesor Intel Core i3

- Operating system Windows 10 Pro-64 bit

b. Smartphone

- Versi android 5.0.2

- Prosesor MT6752 (8 core 1,7 GHz)

- Memori 2 GB

Setelah itu, peneliti membuat media mobile learning berbasis Android menggunakan perangkat tersebut. Pada tahap pengembangan selanjutnya adalah: (2) validasi ahli, yaitu: menguji kelayakan media oleh ahli media dan ahli materi dengan dilanjutkan revisi/ perbaikan, (3) uji coba, yaitu: implementasi media dalam pembelajaran di kelas kemudian meminta penilaian kemudahan dan kemanfaatan penggunaan aplikasi oleh siswa dan guru. 
Pada tahap disseminate (penyebaran) yang dilakukan adalah penyebaran penggunaan media dalam proses pembelajaran mobile learning. Tahap ini merupakan proses pengembangan yang terakhir. Hal ini ditujukan untuk mendistribusikan media untuk siswa dan guru untuk mempermudah proses kegiatan belajar dan mengajar.

\subsection{Subjek Uji Coba}

Subjek uji coba dalam penelitian ini adalah 14 siswa dan 2 guru mata pelajaran Rekayasa Perangkat Lunak di SMK Sultan Trenggono Kota Semarang untuk memperoleh penilaian siswa dan guru terhadap kemudahan dan kemanfaatan penggunaan aplikasi.

\subsection{Teknik Pengumpulan Data}

Teknik pengumpulan data dalam penelitian ini menggunakan observasi, wawancara, dan kuesioner. Instrumen yang digunakan dalam penelitian ini adalah pedoman wawancara, dokumentasi, dan lembar validasi ahli, yaitu: untuk ahli media dan ahli materi.

Observasi dilakukan dengan melakukan pengamatan langsung mengenai kegiatan pembelajaran di sekolah SMK Sultan Trenggono Kota Semarang. Bentuk observasi yang dilakukan bertujuan untuk mendapatkan data awal mengenai kondisi pembelajaran di lingkungan sekolah, seperti: model pembelajaran, sarana prasarana, maupun hambatan/kendala-kendala.

Wawancara dilakukan dengan melakukan komunikasi antara peneliti dengan narasumber untuk memperoleh data atau informasi (Wahyudin, 2015:129). Teknik ini bertujuan untuk mengetahui informasi awal mengenai permasalahan dalam kegiatan pembelajaran untuk memperkuat data hasil pengamatan.

Kuesioner merupakan teknik pengumpulan data untuk memberi pertanyaan atau pernyataan tertulis baik bersifat terbuka maupun tertutup kepada responden untuk dijawab (Sugiyono, 2015:199). Kuesioner digunakan untuk uji validasi dan penilaian siswa dan guru terhadap kemudahan dan kemanfaatan penggunaan aplikasi.

\subsection{Teknik Analisis Data}

Data dalam penelitian ini dianalisis secara deskriptif kualitatif dan deskriptif kuantitatif. Data kualitatif berupa kritik dan saran untuk perbaikan media, sedangkan teknik analisis data kuantitatif digunakan untuk mengubah persentase rata-rata untuk menentukan kriteria: 1) kelayakan media dan 2) penilaian siswa dan guru.

Konversi data kuantitatif ke kualitatif untuk data uji kelayakan media dan penilaian siswa dan guru terhadap kemudahan dan kemanfaatan penggunaan media menurut Sugiyono (2015:144) disajikan dalam tabel berikut.

\begin{tabular}{cc}
\multicolumn{2}{c}{ Tabel 1. Konversi Data Kriteria Kelayakan Media } \\
\hline Persentase Penilaian & Kriteria \\
\hline $76-100 \%$ & Sangat Layak \\
$51-75 \%$ & Layak \\
$26-50 \%$ & Kurang Layak \\
$0-25 \%$ & Tidak Layak \\
\hline
\end{tabular}

Tabel 2. Konversi Data Kriteria Penilaian Siswa dan Guru

\begin{tabular}{cc}
\hline Persentase Penilaian & Kriteria \\
\hline $76-100 \%$ & Sangat Baik \\
$51-75 \%$ & Cukup Baik \\
$26-50 \%$ & Kurang Baik \\
$0-25 \%$ & Sangat Tidak Baik \\
\hline
\end{tabular}

\section{HASIL DAN PEMBAHASAN}

3.1 Hasil Pengembangan Media Mobile Learning 3.1.1 Pendefinisian (define)

1) Analisis ujung depan

Analisis ujung depan dilakukan dengan mendiagnosis permasalahan dasar yang dialami oleh siswa SMK Sultan Trenggono jurusan Rekayasa Perangkat Lunak dalam proses pembelajaran. Teknik yang dilakukan adalah observasi dan wawancara. Berdasarkan observasi dan wawancara yang dilakukan pada bulan Januari 2018, salah satu permasalahan yang terdapat dalam kegiatan pembelajaran di SMK Sultan Trenggono adalah media pembelajaran yang digunakan belum layak, monoton, sulit dipahami, dan kurang menyenangkan. Selain itu, implementasi mobile learning berbasis Edmodo yang telah digunakan hanya untuk try out atau latihan ujian dan belum dioptimalkan dalam proses pembelajaran. Oleh karena itu, peneliti memutuskan untuk melakukan pengembangan media m-learning berbasis android sebagai media pembelajaran yang dapat digunakan di kelas sehingga dapat membantu siswa memahami materi yang sulit dan mengatasi perbedaan kecepatan pemahaman materi dalam proses belajar mengajar secara klasikal.

2) Analisis Siswa

Analisis siswa berfungsi untuk penyesuaian metode pembelajaran dengan karakteristik siswa dan kesulitan yang dialami. Siswa kelas X SMK Sultan Trenggono berusia sekitar 16-17 tahun dan mereka tertarik jika pembelajaran menggunakan smartphone. Selain itu mereka mengalami kesulitan dalam memahami materi pelajaran pemrograman dasar. Hal ini menjadi pertimbangan untuk menyusun materi pembelajaran yang akan dikemas dalam pengembangan media. Materi pembelajaran disusun dengan sistematis dan dilengkapi dengan latihan dan metode demonstrasi untuk menunjukkan proses agar lebih mudah dipahami.

3) Analisis Tugas, Konsep, dan Tujuan

Pembelajaran

Analisis tugas dilakukan dengan mengidentifikasi penjabaran materi sesuai dengan tugas siswa, 
meliputi: analisis terhadap kompetensi inti (KI) dan kompetensi dasar (KD). Analisis konsep dilakukan dengan menentukan materi dan media yang akan dikembangkan sesuai kurikulum jurusan Rekayasa Perangkat Lunak. Kemudian tujuan pembelajaran ditentukan berdasarkan analisis tugas dan konsep. Berdasarkan tujuan pembelajaran lalu ditentukan indikator pencapaian siswa dalam pembelajaran. Hasil analisis tugas, konsep, dan tujuan pembelajaran dapat dilihat pada tabel berikut.

Tabel 3. Hasil Analisis Tugas, Konsep, dan Tujuan Pembelajaran

\begin{tabular}{|c|c|c|}
\hline No & \multicolumn{2}{|c|}{ ibelajar } \\
\hline$\frac{100}{1}$ & Kompetensi Inti & $\begin{array}{l}\text { Memahami, menerapkan, } \\
\text { menganalisis, dan mengevaluasi } \\
\text { tentang pengetahuan faktual, } \\
\text { konseptual, operasional dasar, } \\
\text { dan metakognitif sesuai dengan } \\
\text { bidang dan lingkup kerja } \\
\text { Rekayasa Perangkat Lunak pada } \\
\text { tingkat teknis, spesifik, detil, } \\
\text { dan kompleks, berkenaan } \\
\text { dengan ilmu pengetahuan, } \\
\text { teknologi, seni, budaya, dan } \\
\text { humaniora dalam konteks } \\
\text { pengembangan potensi diri } \\
\text { sebagai bagian dari keluarga, } \\
\text { sekolah, dunia kerja, warga } \\
\text { masyarakat nasional, regional, } \\
\text { dan internasional. }\end{array}$ \\
\hline 2 & $\begin{array}{l}\text { Kompetensi } \\
\text { Dasar }\end{array}$ & $\begin{array}{l}\text { Menerapkan pembuatan } \\
\text { antarmuka (user interface) pada } \\
\text { aplikasi. }\end{array}$ \\
\hline 3 & Materi & User Interface \\
\hline 4 & $\begin{array}{l}\text { Tujuan } \\
\text { Pembelajaran }\end{array}$ & $\begin{array}{l}\text { 1. Siswa dapat mengkonsepkan } \\
\text { tentang antarmuka secara } \\
\text { umum. } \\
\text { 2. Siswa dapat mengemukakan } \\
\text { komponen antarmuka dan } \\
\text { prinsip desain antarmuka. } \\
\text { 3. Siswa dapat menerapkan } \\
\text { antarmuka aplikasi } \\
\text { menggunakan software MIT } \\
\text { App Inventor. }\end{array}$ \\
\hline
\end{tabular}

\subsubsection{Perancangan (design)}

Tahap ini dilakukan perencanaan produk sebagai media pembelajaran berbentuk mobile learning berbasis Android pada mata pelajaran Rekayasa Perangkat Lunak kelas X semester 2 dengan pokok bahasan user interface. Perancangan ini meliputi 3 tahap, yaitu sebagai berikut.

\section{1) Penyusunan Tes Acuan}

Tes ini bertujuan untuk mengukur kemampuan pemahaman siswa dalam pembelajaran menggunakan mobile learning berbasis Android. Tes disusun berdasarkan kompetensi inti (KI) dan kompetensi dasar (KD) dan indikator pencapaian kompetensi. Tes acuan yang dimaksud dapat dilihat dalam tabel berikut ini.

\begin{tabular}{|c|c|c|}
\hline $\begin{array}{l}\text { Kompetensi } \\
\text { Dasar }\end{array}$ & $\begin{array}{ll}\text { Indikator } & \text { Pencapaian } \\
\text { Kompetensi } & \end{array}$ & $\begin{array}{l}\text { Butir } \\
\text { Soal }\end{array}$ \\
\hline $\begin{array}{l}\text { Menerapkan } \\
\text { pembuatan antar } \\
\text { muka } \\
\text { interface) } \\
\text { aplikasi. }\end{array}$ & $\begin{array}{l}\text { 1. Siswa dapat } \\
\text { mengkonsepkan tentang } \\
\text { antarmuka secara umum. } \\
\text { 2. Siswa dapat } \\
\text { mengemukakan } \\
\text { komponen antarmuka } \\
\text { dan prinsip desain } \\
\text { antarmuka. } \\
\text { 3. Siswa dapat menerapkan } \\
\text { antarmuka aplikasi } \\
\text { menggunakan software } \\
\text { MIT App Inventor. }\end{array}$ & $\begin{array}{l}\text { PG: } 8 \\
\text { PG: } \\
12\end{array}$ \\
\hline
\end{tabular}

2) Pemilihan Media

Berdasarkan analisis pada tahap pendefinisian (define) media yang dikembangkan adalah mobile learning berbasis Android pada mata pelajaran Rekayasa Perangkat lunak kelas X semester 2 SMK Sultan Trenggono dengan pokok bahasan user interface.

3) Pemilihan Format

Format yang dipilih adalah pemanfaatan media mobile learning berbasis Android yang memenuhi kriteria kelayakan menurut Depdiknas (2008:28) dengan 4 aspek, meliputi: isi, kebahasaan, sajian, dan kegrafikan. Hal ini ditujukan untuk menjadikan proses pembelajaran yang optimal dengan pemanfaatan smartphone milik siswa. Format mobile learning berbasis android sebagai berikut.

a. Media

Media berupa aplikasi Android dengan bentuk penyajian sebagai berikut.

1) Terdapat 6 menu utama, yaitu: kompetensi dasar, petunjuk aplikasi, materi, evaluasi, konsultasi guru, dan profil.

2) Materi yang ditampilkan berupa teks yang dapat di scroll vertikal, gambar, dan video.

3) Video berupa tutorial praktikum sesuai dengan materi yang disajikan.

4) Ikon gambar aplikasi berupa kependekan dari judul materi yaitu "ui", berasal dari user interface.

b. RPP (Rencana Perangkat Pembelajaran)

RPP (Rencana Perangkat Pembelajaran) yang disusun disesuaikan dengan silabus SMK jurusan Rekayasa Perangkat Lunak berbasis kurikulum 2013 yang dapat dilihat pada lampiran 1 halaman 88 .

c. Sumber Belajar

Sumber belajar dari materi yang disajikan dalam media mobile learning berbasis Android mata pelajaran Rekayasa Perangkat Lunak disesuaikan dengan tujuan pembelajaran, yaitu: buku dan artikel. 4) Rancangan Tampilan

Berikut ini bagian dari beberapa hasil rancangan tampilan aplikasi "User Interface". 


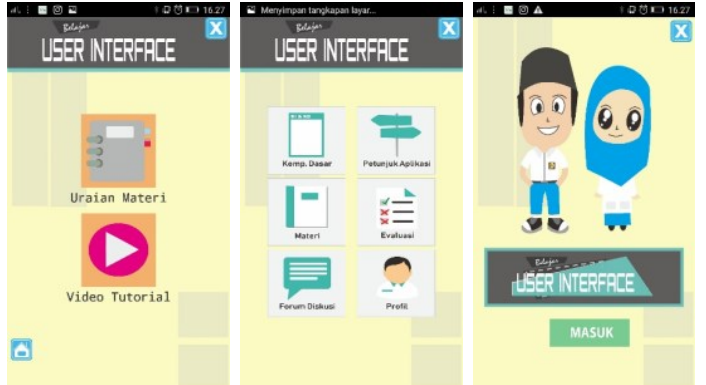

Gambar 3. Hasil Rancangan Tampilan Menu Aplikasi "User Interface"

\subsubsection{Pengembangan (develop)}

Tahap pengembangan yang dilakukan adalah pembuatan aplikasi "User Interface" menggunakan software MIT App Inventor, Corel Draw X5, Adobe Premiere CS 6, dan program lainnya. Kemudian dilanjutkan dengan proses validasi oleh validator media dan materi untuk mengetahui tingkat kelayakan media mengunakan lembar penilaian berupa angket dengan aspek-aspek yang telah disesuaikan dengan Depdiknas (2008:28). Setelah media dinilai layak dan selesai revisi (perbaikan) maka diujicobakan pada proses pembelajaran dan mendapat penilaian kemudahan dan kemanfaatan penggunaan aplikasi oleh guru dan siswa menggunakan lembar penilaian berupa angket.

\subsubsection{Penyebaran (disseminate)}

Setelah media mobile learning diuji validasi mencapai nilai kelayakan dan menunjukkan kebermanfaatan dan kemudahan penggunaan aplikasi oleh guru dan siswa maka media dapat disebarkan ke siswa SMK Sultan Trenggono untuk digunakan dalam pembelajaran berikutnya melalui fasilitas laboratorium komputer milik sekolah yang dipindahkan melalui kabel data, bluetooth, flashdisk maupun DVD (Digital Versatile Disc).

\subsection{Hasil Uji Coba}

Produk akhir pengembangan media mobile learning berupa aplikasi android sebagai paket pembelajaran mata pelajaran Rekayasa Perangkat Lunak materi pemrograman dasar dengan pokok bahasan penerapan user interface yang terdiri dari satu kompetensi dasar, yaitu: menerapkan user interface dengan tiga tujuan pembelajaran, diantaranya: (1) siswa akan mengkonsepkan tentang user interface secara umum; (2) siswa akan mengemukakan komponen user interface dan prinsip desain user interface; dan (3) siswa akan menerapkan user interface pada aplikasi menggunakan software MIT App Inventor. Aplikasi android disajikan dalam bentuk file android package (apk) yang dapat dipasangkan pada smartphone berbasis android. Media dapat digunakan oleh pengguna khususnya siswa untuk proses pembelajaran di kelas. Aplikasi android ini berjudul "User Interface".

Aplikasi "User Interface" terdiri dari 6 menu utama, yaitu: (1) kompetensi dasar berisi tentang informasi kompetensi dasar dan tujuan pembelajaran; (2) petunjuk aplikasi berisi tentang penjelasan ikon tombol, navigasi, dan fungsinya ; (3) materi berisi rangkuman materi dan video tutorial sebagai pendukung konten; (4) evaluasi berisi 20 latihan soal dan hasil nilai pengerjaan; (5) konsultasi guru berisi halaman untuk mengirim pesan kepada guru melalui fitur gmail; dan (6) profil berisi tentang informasi identitas pengembang.

Media diuji kelayakannya untuk mengukur kualitas media dari segi media dan materi. Pengambilan data kelayakan media diperoleh dari penilaian oleh validator media yang terdiri dari: 2 ahli media dan 2 ahli materi melalui kuesioner. Parameter untuk mengukur kualitas media menggunakan 4 syarat kelayakan menurut Depdiknas (2008:28), yaitu: isi, kebahasaan, sajian, dan kegrafikan dimodifikasi dengan standar kualitas ISO (International Standards Organisation) 9126 dalam Dwi, Insan, dan Rochimah (2014:88), kemanfaatan (Harlan, 2014:42) serta kemudahan penggunaan media (Kemp dan Dayton dalam Falahudin, 2014:114). Kemudian data penilaian kemudahan dan kemanfaatan penggunaan aplikasi diperoleh dari tanggapan siswa dan guru melalui lembar penilaian berupa kuesioner.

Tabel 5. Hasil Penilaian Ahli Media

\begin{tabular}{ccl}
\hline No & Validator & Skor \\
\hline 1 & Ahli Media 1 & 82 \\
2 & Ahli Media 2 & 71 \\
Jumlah Skor Total & 153 \\
Jumlah Skor Maksimal & 176 \\
Persentase Kelayakan & $86,93 \%$ \\
Kriteria & Sangat Layak
\end{tabular}

Tabel 6. Hasil Penilaian Ahli Materi

\begin{tabular}{cll}
\hline No & Validator & Skor \\
\hline 1 & Ahli Materi 1 & 87 \\
2 & Ahli Materi 2 & 87 \\
Jumlah Skor Total & 174 \\
Jumlah Skor Maksimal & 200 \\
Persentase Kelayakan & $87 \%$ \\
Kriteria & Sangat Layak \\
\hline
\end{tabular}

Berdasarkan Tabel 1 menunjukkan bahwa secara keseluruhan hasil validasi dari ahli media yaitu $86,93 \%$ dan termasuk kategori sangat layak. Selanjutnya hasil validasi ahli materi dapat dilihat dari Tabel 2 yang menunjukkan persentase kelayakan sebesar $87 \%$ dan termasuk kategori sangat layak. Setelah media diuji kelayakan maka dilakukan perbaikan dan media siap diujicobakan pada proses pembelajaran.

Berikut perolehan persentase dari tiap aspek kemudahan dan kemanfaatan penggunaan aplikasi Android sebagai media pembelajaran mobile learning disajikan dalam tabel berikut. 
Tabel 5. Hasil Penilaian Kemudahan dan Kemanfaatan

\begin{tabular}{clllll}
\hline No & R & Aspek & Skor & P (\%) & Kriteria \\
\hline \multirow{2}{*}{1} & \multirow{2}{*}{ Guru } & Kemudahan & 40 & \multirow{2}{*}{87,5} & Sangat \\
& & Kemanfaatan & 58 & & Baik \\
\multirow{2}{*}{2} & \multirow{2}{*}{ Siswa } & Kemudahan & 265 & & Sangat \\
& & Kemanfaatan & 380 & 82,27 & Baik
\end{tabular}

Keterangan:

$\mathrm{R}$ : responden

$\mathrm{P}$ : persentase

Berdasarkan Tabel 3 menunjukkan bahwa siswa dan guru berpendapat bahwa media mobile learning berupa aplikasi android ini memiliki nilai kemudahan dan kemanfaatan sangat baik sehingga dapat digunakan dalam proses pembelajaran.

Hasil ini sesuai dengan penelitian Astra, Nasbey, dan Nugraha (2015) yang menghasilkan media berupa aplikasi android yang layak untuk diujicobakan dalam proses pembelajaran dengan perbedaan penambahan fitur dalam media mobile learning berupa exercise atau latihan soal berupa soal pilihan ganda dengan 4 opsi jawaban. Bahkan penelitian ini tidak hanya mengukur kelayakan media seperti dalam penelitian Lu'mu (2017) akan tetapi ditambahkan penilaian kemanfaatan dan kemudahan penggunaan media oleh siswa dan guru.

Selain itu, berdasarkan penelitian Ibrahim dan Ishartiwi (2017) melakukan pengembangan media berupa aplikasi android menggunakan software eclipse helios, sedangkan penelitian ini mengembangkan menggunakan software MIT App Inventor yang lebih mudah penggunaannya terkait dengan penulisan sintaks dalam program. Hal ini didukung oleh Arsyad (2014:74) menjelaskan bahwa ketika memilih media pembelajaran harus memperhatikan kemudahan memperoleh media, yaitu: media sudah ada, mudah diperoleh, atau mudah dibuat sendiri oleh guru, dan fleksibel (media dapat digunakan kapanpun, dimanapun, dan mudah dibawa).

Selain itu, media mobile learning ini memiliki beberapa kelebihan dan kekurangan. Hal ini diperoleh dari pernyataan ahli media, ahli materi, dan pengguna (guru dan siswa) melalui kuesioner maupun wawancara. Adapun kelebihan dari media mobile learning ini, yaitu: (1) produk media berupa android package (apk) dengan size kurang dari 5MB, (2) penyajian materi dalam aplikasi sistematis dan mudah dioperasikan, dan (3) media bersifat interaktif sehingga diharapkan dapat menarik minat siswa untuk belajar. Selain kelebihan, media mobile learning ini memiliki beberapa kekurangan, diantaranya: (1) perlunya tersambung data internet untuk mengakses konten video dalam aplikasi, (2) beberapa kualitas gambar yang kurang dikarenakan keterbatasan memori untuk membangun aplikasi.

\section{KESIMPULAN}

Berdasarkan hasil penelitian, peneliti memberikan beberapa simpulan, yaitu sebagai berikut.

1. Pengembangan media mobile learning berbasis Android menggunakan model 4 D (Four D) Models yaitu, define (pendefinisian), design (perancangan), develop (pengembangan), dan disseminate (penyebaran).

2. Aplikasi mobile learning "User Interface" yang dikembangkan telah divalidasi oleh ahli media dan ahli materi dengan mendapat penilaian sebesar $86,93 \%$ dari ahli media dan $87 \%$ dari ahli materi. Hal ini menunjukkan bahwa media mobile learning yang dikembangkan layak untuk diujicobakan pada pembelajaran.

3. Berdasarkan uji coba pada pembelajaran di kelas, aplikasi mobile learning mendapat penilaian terhadap kemudahan dan kemanfaatan penggunaan aplikasi sebesar $87,5 \%$ oleh guru dan $82,27 \%$ oleh siswa. Hal ini menunjukkan bahwa media mobile learning memiliki kemudahan dan kemanfaatan penggunaan aplikasi untuk kegiatan belajar dan mengajar.

\section{DAFTAR PUSTAKA}

AMIRULLAH, G. dan R. HARDINATA. 2017. Pengembangan Mobile Learning bagi Pembelajaran. Jurnal Kesejahteraan Keluarga dan Pendidikan, 4(2), pp:97-101.

ARIPUTRI, G.A. dan E. SUPRAPTONO. 2015. Peningkatan Hasil Belajar English Listening Skill dengan Menggunakan Aplikasi "SMARTY WAY" Berbasis Android. Edu Komputika Journal, 2(1), pp.38-47.

ARSYAD, A. 2014. Media Pembelajaran. Edisi Revisi. Cetakan ke-17. Jakarta: Rajawali Pers.

AZIZAH, N., B. B. BUTAR, dan I. T. WAHYUNI. 2018. Animasi Interaktif Pengenalan Dasar Bahasa Inggris pada TK An-Nuruddin Depok. Innovative Creative and Information Technology, 4(1), pp.29-40.

CHANDRA, Y. I. 2016. Aplikasi Pembelajaran Angka, Bentuk, Huruf dan Warna Untuk Anak-Anak Menggunakan Metode Computer Assisted Instruction (CAI) Berbasis Android. Jurnal Ilmiah Komputasi, 15(1), pp.7-13.

DARMAWAN, D. 2016. Mobile Learning Sebuah Aplikasi Teknologi Pembelajaran. Edisi Pertama. Cetakan Pertama. Jakarta: Rajawali Pers.

DEPDIKNAS. 2008. Panduan Pengembangan Bahan Ajar: Direktorat Pembinaan Sekolah Menengah Atas.

DWI P, G. A., R. F. INSAN M, dan S. ROCHIMAH. 2014. Pengukuran Kualitas untuk Aplikasi 
Permainan pada Perangkat Bergerak berdasarkan ISO 9126. ULTIMA InfoSys, 5(2), pp.83-90.

FALAHUDIN, I. 2014. Pemanfaatan Media dalam Pembelajaran. Jurnal Lingkar Widyaiswara, 1(1), pp.104-117.

FALAHUDIN, I. 2014. Pemanfaatan Media dalam Pembelajaran. Jurnal Lingkar Widyaiswara 1(1), pp.104-117.

HAFIS, M. dan SUPIANTO, A.A. 2018. Mobile Game Design for Learning Chemical Bonds with Endless Run Approach. International Journal of Interactive Mobile Technologies, 12(8), pp.104-111.

HARLAN, D. 2014. Pengaruh Kemudahan Penggunaan, Kepercayaan, dan Risiko Persepsian Terhadap Minat Bertransaksi Menggunakan E-Banking pada UMKM di Kota Yogyakarta. Skripsi. Akuntansi Universitas Negeri Yogyakarta. Yogyakarta.

HARTINI, S HAPSARI, W., H. WIBAWANTO, dan I. M. SUDANA. 2017. Pengembangan Mobile Learning Teknik Digital Bagi Mahasiswa Pendidikan Teknik Elektro. Journal of Vocational and Career Education, 2(1), pp.28-36.

HERLAMBANG, A.D. dan W.N. NUR HIDAYAT. 2016. Edmodo untuk Meningkatkan Kualitas Perencanaan Proyek dan Efektivitas Pembelajaran di Lingkungan Pembelajaran yang Bersifat Asinkron. Jurnal Teknologi Informasi dan Ilmu Komputer (JTIIK), 3(1), pp.1-8.

KAWURYAN, S. P. 2014. Peningkatan Kreativitas Calon Guru dalam Pembuatan Media Berbasis ICT Melalui Project Based Learning pada Mata Kuliah Pengembangan Pembelajaran IPS SD, 21(1), pp.57-74.

LU'MU. 2017. Learning Media Of Applications Design Based Android Mobile Smartphone. International Journal of Applied Engineering Research, 12(17), pp.65766585.

MUHARUM, A. M., V. T. JOYEJOB, V. HURBUNGS, dan Y. BEEHARRY. 2017. Enersave API: Android based power saving framework for mobile devices. Future Computing and Informatics Journal 2(1), pp.48-64.

MUYAROAH, S. dan M. FAJARTIA. 2017. Pengembangan Media Pembelajaran Berbasis Android dengan menggunakan Aplikasi Adobe Flash CS 6 pada Mata Pelajaran Biologi. Innovative Journal of Curriculum and Educational Technology, 6(2), pp.79-83.
PUTRANTI, N. 2013. Cara Membuat Media Pembelajaran Online Menggunakan Edmodo. Jurnal Pendidikan Informatika dan Sains, 2(2), pp.139-147.

ROTONDI, V., L. STANCA, dan M. TOMASUOLO. 2017. Connecting alone: Smartphone use, quality of social interactions and well-being. Journal of Economic Psychology 63, pp.17-26.

SETIAWAN, I. F. ASTUTI, dan D. M. KHAIRINA. 2014. Rancang Bangun Game Edukasi Berbasis Android Tebak Lagu Nusantara: Senara. Jurnal Informatika Mulawarman, 9(2), pp.24-30.

SUGIYONO. 2015. Metode Penelitian Pendidikan. Bandung: Alfabeta.

SYAFRIZAL, A., ERNAWATI, dan B. Y. DWIANDIYANTA. 2015. Penerapan Model Technology Acceptance Model (TAM) untuk Pemahaman Media Pembelajaran Berbasis Multimedia Interaktif. Scientific Journal of Informatics, 2(1), pp.9-14.

TAUFIQ, M., A. V. AMALIA, dan PARMIN. 2017. The Development of Science Mobile Learning With Conservation Vision Based On Android App Inventor 2. Unnes Science Education Journal, 6(1), pp.1472-1479.

WAHYUDIN, A. 2015. Metodologi Penelitian. Semarang: Unnes Press.

WIBAWANTO, W. 2017. Desain dan Pemrograman Multimedia Pembelajaran Interaktif. Jember: Penerbit Cerdas Ulet Kreatif. 